\title{
GÜNCEL SANATTA TEKSTIL HEYKELLERIN TEMSIL NiTELIĞi
}

\section{REPRESENTATIVE QUALITY OF TEXTILE IN CONTEMPORARY ART}

\author{
Nazan Özcan ${ }^{*}$, K. Özlem Alp**
}

\section{Öz}

1960'Iı yıllarla birlikte değişen sosyo-ekonomik ve kültürel ortam, sanata ilişkin tüm kavram ve uygulamaları yeni temsil arayışları çerçevesinde değiştirmiştir. Genel olarak, geleneksel sanatlar ve zanaat başlığı altında temsil edilen tekstil sanatı, geleneksel işlevinden farklı olarak malzeme ve tekniğin yeni aktarım olanaklarına yönelmiştir. Bu araştırmada tekstilin 60 sonrası temsil niteliğindeki dönüşümleri ve 1980 sonrası tekstil heykellerin temsil nitelikleri tartışılmıştır. 1960’lı yıllar tekstilin yapısal özelliklerinin yeniden keşfedildiği ve kavramsallaştığı yıllardır. 1980'li yıllar ise tekstil sanatının kendi varoluş sınırını aşması ile ayağa kalktığı, tekstilin heykel olarak güncel sanata eklendiği, onun malzeme ve teknik boyutunu aşarak, güncel sanatın kimi ilgi alanlarına yöneldiği yıllardır. Bu bakımdan bu araştırmada, güncel sanatta tekstil heykellerin temsil anlayışı; zaman-mekan-sınırlar, beden-kimlik, coğrafya, ekolojik dengeler, demokrasi, cinsiyet, öteki, gelenek ve çağdaşlık gibi güncel yaşamın kimi konularına sosyo-politik ve eleştirel yaklaşımları da içeren örnekler üzerinden incelenmiştir.

Anahtar Kelimeler: Güncel Sanat, Tekstil Heykeller, Temsil, Lif.

\begin{abstract}
Together with 1960's, changing socio-economic and cultural media changed all conceptions and applications regarding art within the representation frame. Textile art, generally represented under the title of traditional art and craft, oriented to new transport facilities of material and technique unlike from its traditional functions. In this research, changes in representative quality of textile after 60 , and textile sculptures after 80 have been discussed. 1960's are the years of re-discovering and reconceptualizing distinctive structural properties of textile. 1980's are the years of textile art standing-up by passing the boundaries of its existence, by attaching to the contemporary art as sculpture, by orienting to some of its interest areas as going beyond the dimensions of its material and techniques. That's why in this research representation mentality of textile sculptures in contemporary art has been investigated on the basis of samples involving some subjects of contemporary life through socio-politic and critical approaches such as time-space-border lines, body-identity, geography, ecologic equilibrium, democracy, gender, other, tradition and contemporary.
\end{abstract}

Keywords: Contemporary Art, Textile Sculpture, Representation, Fiber.

Derleme Makale // Başvuru tarihi: 07.02.2020 - Kabul tarihi: 06.06.2020.

*Öğr. Gör., Tekirdağ Namık Kemal Üniversitesi, Teknik Bilimler Meslek Yüksek Okulu, Tekstil, Giyim, Ayakkabı ve Deri Bölümü/Tekstil Teknolojisi Programı, nozcan@nku.edu.tr, https://orcid.org/0000-0001-5352-3735.

** Doç. Dr., Ankara Hacı Bayram Veli Üniversitesi, Sanat ve Tasarım Fakültesi, Görsel Sanatlar Bölümü, k.ozlem.alp@gmail.com, https://orcid.org/0000-0002-2444-8446. 


\section{Giriş}

Modernizmden bir kopuş ya da modernizmin toplumsal dönüşümünde kendini yeniden üreten bir süreç ve durum olarak ele alınan postmodernizm (Best\&Douglas, 2011; Featherstone, 2005; Şaylan, 2009; Jameson, 2011; Lyotard, 1994) 1960'lı yıllardan itibaren sosyo-ekonomik, sosyo-kültürel, bilimsel ve teknolojik dönüşümlerle birlikte göreceli olarak bir kültür kuramı çerçevesinde önemli tartışmalara neden olmuştur. Postmodern durum tanımlaması kuramsal olarak olduğu kadar, 60 sonrası değişen yenidünya düzeni ile birlikte modern sanatın araç, sağlayıcı ve dolanımından yola çıkarak; yapıt, alıcı, sanatçı ve sektör bağlamında büyük bir dönüşümü getirmiştir. Bürger (2014)'in tarihsel avangard olarak tanımladığı Dada hareketiyle başlayan ve sonrasında aşağı yukarı 60'lı yıllarda ortaya çıkan kavramsal sanat uygulamaları modern sanatın artık geri dönüşü olmayacak bir şekilde temsil niteliğini değiştirmiştir. Bu dönüşümün pek çok nedeni olmakla birlikte özetle, toplumsal ve ekonomik alt yapı ilişkilerine koşut olarak, sanatçıların modern sanatın biçimciliğine, yaşamdan ve gündelik hayattan kopuk olmasına, ticarileşmesine ve kurumsallaşmasına karşı oluşlarında aranabilir. Bu bakımdan, 1960-1980 arası oluşan sanat rejimi, modern sanatın biçim dilini, estetiğini, malzemesini, konusunu, içeriğini ve felsefesini tamamen değiştiren uygulamalara odaklanmıştır. Protest bir tavırla ortaya çıkan bu ilk uygulamaların açtığı yol, sanatın, sanat eserinin, sanatçının ve hatta sanat tarihinin tarihsel konumunu yeniden tanımlamayı gerektirmiştir. Sanatçıların yeni malzemeleri ve yeni anlatım olanaklarını özgürce kullanmaları Yılmaz'ın (2006:347) da belirttiği gibi modernizmin seçkinciliğine karşılık, farklı disiplin ve biçemlerden oluşan bir çoğulculuğun öne çıkması, bu dönemin başat özelliklerindendir.

Whitham ve Pooke (2013:93) çağdaş sanatın, yaşadığı çağın sanat anlayışı ve sanat alanı dışındaki tüm disiplinlerle etkileşim içerisinde farklı ortam ve sanatsal disiplinlerin birleştirildiği karma bir disiplin haline geldiğini ifade etmiştir. Öte yandan sanatın gündelik yaşamla buluşan postmodern hali, moda, tekstil, tasarım, dekorasyon v.b tüm alanları buluşturmuştur. Bu belki de modernizmin tanımladığı kültürün uzun zamandır kapanmış olan kollarını gündelik yaşama açması anlamına da gelmiştir. Böylece sadece sanat değil, sanatla birlikte kültürün de modern formunun değiştiğini, yeni ve postmodern bir kültür formunun ortaya çıktığını söylemek abartılı bir söylem olmayacaktır. 
Tüm bu elverişli ortam hemen 1960 'lı yıllarda tekstilin geleneksel kullanım biçimi ve temsil niteliğini değiştirerek sanatçılara yeni ifade olanaklarının kapısını açmıştır. Bu yeni ifade olanaklarını oluşturan yeni nesneler, yeni malzemeler ve teknikler sanat nesnesinin bir kez daha yeniden tanımlanmasını getirmiştir. Farago (2006:248)'nun da belirttiği gibi, sanatçının ait olduğu topluluk adına sanat eseri olarak ilan ettiği her yaratım artık sanat eseri olarak kabul edilmektedir. Kuşkusuz bu tanım sanat eserinin artık çok geniş bir çerçevede ele alınmasını ve çoğu kez tanımlanamamasını da gündeme getirmiştir. Öte yandan sanat nesnesini oluşturan malzemenin niteliği, belki de tüm sanat tarihi boyunca bu kadar felsefi bir derinliğe ulaşmamıştır. Çünkü malzeme neticede, bir kavram, bir düşünce, bir durum ya da duyguyu oluşturacak olan sanat nesnesinin verisidir. Malzemenin doğal ya da yapay ham bir veri olarak ele alınması ve bu malzemeyle oluşturulan sanat nesnesinin bu anlamda statüsüzleştirilmesi ve böylece statüsüzlük statüsü kazanması güncel sanatın en önemli kavrayışlarından birisi olmuştur. İngiliz sanat tarihçisi Marcia Pointon, sanat tarihinin sadece bir çeşit nesne grubuyla ilgilenmediğini, mobilyadan, seramiğe, resimden tekstil ve çaydanlığa kadar her insan yapısı, yapı ve nesnenin sanat tarihçisinin yetki alanına girdiğini belirtmektedir (Barnard, 2002:75).

1960'lı yılların başından itibaren başlayan bu tartışmalar bir bakıma sanat kavramını kapsayan tüm alanların yeniden tanımlanmasını gerektirmiştir. Bu aynı zamanda sanat için bir kriz anlamına da gelmektedir. Öyle ki Akay (2010:23)'ın da belirttiği gibi, Sanat bir disiplin olarak işlerliğini yitirmiştir. Ancak asla "disipline edilemez" olan olarak ele alınabilir. Her bir disiplinin kendi alanını terk ettiği, yani yersiz yurtsuzlaşmaya başladığı bir zamanda, artık sanatın alanlarından da bir meşruluk alanı olarak bahsetmek zor hale gelmiştir. Tam da bu noktada hem teknik, hem de kullanım olarak geleneksel kabul edilen ve hatta çoğunlukla el sanatları bağlamında ele alınan tekstil kavramı, bu alanda uzun yıllar boyunca emek veren sanatçıların 1960'ı yıllarla birlikte lifin plastik yapısını öne çıkaran çağdaş çalışmalara yönelmelerini ve zor da olsa kendilerine çağdaş sanatta önemli bir yer edinmelerini sağlamıştır.

Geçmişle bağı kopmuş ve artık yeni yaratılarla kendine ifade imkanı bulmuş "Güncel Sanat" bu hareketlilik ve farklılıklarla mimari, tiyatro, sinema, resim, seramik gibi birçok alanda etkisini gösterirken, tekstil alanında da güçlü öğeler olarak ortaya çıkmıştır. Sanat, zanaat, tarih, teknoloji ve teknoloji ürünleri materyallerinin bir arada kullanılması ile 
kurumsal estetik ve güçleri ortaya çıkaran "Lif Sanatının" doğuşuna zemin hazırlanmıştır (Auther, 2008:13).

Tekstilin, 1960 sonrası geleneksel sınırlarından kurtularak güncel sanatta yeni bir temsil türü olarak ortaya çıkışı, yeni ifade olanaklarının araştırılması ve giderek malzemenin aktarımında boyut kazanarak heykel formlarına dönüşmesi bu araştırmanın ana konusudur. Bu bakımdan, bu çalışmada, tekstil sanatının 60 sonrası nasıl ve ne şekilde yeni ifade olanakları bulduğu ve 70 sonrası güncel sanatın yönelimleri içinde yeni bir tür olarak yer alan tekstil heykeller örneklerle birlikte ele alınarak kavramsal düzeyde tartışılmıştır.

\section{1960 Sonrası Güncel Sanatta Tekstil Sanatının ifade Biçimleri}

Tekstilin Avrupa'da gündelik yaşamda kullanımının dışında 20. yüzyıla kadar, duvar halısı, kumaş vb. dekoratif amaçlarla kullanıldığı bilinmektedir. Ancak özellikle Bauhaus Okulu 20. yüzyılın başında hızlı bir gelişme gösteren endüstri ile birlikte sanat ve zanaat kavramlarını, estetik ve bütünsel bir anlayışla ele alıp, sanat ve yaşamı, başka bir söyleyişle işlev ve estetiği birleştirme çabasında olmuştur. Bu çaba tekstilin sanat alanında bir yer edinebilmek için öne çıkmasına büyük bir katkı sağlamıştır. Anni Albers (Yaşar, 2019), Gunta Stölzl ve Otti Berger gibi bu okulda yetişmiş olan sanatçıların uzun yıllar süren çabaları da tekstilin bir sanat alanı olmasında etkili olmuştur (Gürcüm ve Kartal, 2017:1785). Ancak tekstilin sanatsal bir ifade aracı olarak var olması için 1960 sonrasını beklemesi gerekmiştir.

1960'। y yıllar tekstil sanatının henüz kavramsal sanat içinde yer bulmaya çalıştığı yıllardır. Genel bir belirlemeyle kumaş, ip, keçe ve lif malzemeleri bu yıllarda malzemenin yeni olanaklarının keşfedildiği ve özellikle lifin ön plana çıktığı dönemlerdir. Lifin doğal olduğu kadar güncel yaşamın içinde duran, hem samimi hem de alternatif yapısı, alışılagelmiş "plastik" imlemeyi aşan yanı, en çok tercih edilen malzeme olmasını etkilemiştir. Malzemenin alternatif yapısına ek olarak dönemin kavramsal temsil mantığı, malzemenin bu temsil içinde yeniden canlanmasını sağlamıştır. Tapies (2014:32), malzemelerin kendi başına cansız olduklarını, eserin duygulandırma gücünün sanatçının bazı fikirleri en uygun zamanda işleme koymaktaki becerisinde yattığını, gerçek bir sanat eserinin özünde seyircide bir vicdan muhasebesini hissettirmesini ve seyircinin tüm kavramsal alanını yeniden gözden geçirmek intiyacını yaratması gerektiğini belirtmektedir.

Sanat anlayışındaki kökten değişimin getirdiği yeni arayışlar Arabalı (2017:2037)'nın belirttiği gibi, lif sanatında disiplinlerarası etkileşimin, diğer sanat alanları arasındaki katı 
sınırları ortadan kaldırmış, malzeme, teknik ve uygulama bakımından etkileşimleri güçlenen elyaf yeni sanatsal yaratılarla kendini ifade etme imkânı bulmuştur. 1960'tan sonra resim ve heykel arasındaki sınır, resim gibi heykel, heykel gibi resimlerin yapılması sonucu ortadan kalkmış, "art object" yani sanat objeleri diye yeni bir tanım ortaya çıkmıştır. 1965'ten sonra da çevresel ve kavramsal sanatların önem kazanması ile sanatın sınırları daha da genişlemiştir (Alpan, 1986:101). Böylelikle elyafın şekil alabilme, aldığı şekli koruyabilme gibi özellikleri güncel sanata hizmet edebilen bir araç olmasını sağlamış, sanatçıların kişisel ifadelerini aktardıkları özgün kavramsal eserler üretmeye başladıkları, yapıtlarını çeşitli platformlarda sunma imkanı buldukları, el sanatı tanımının önüne geçerek malzemenin tüm potansiyelinin farkına varıldığı, kendi yasalarına sahip bir sanat dalı haline gelmiştir (Braddock and O'Mahony, 1997:158).

1960 ve 70'li yıllarda lif sanatı, tekstil kökenli sanatçıların klasik dokuma tekniklerini aşarak, öncü sergiler düzenlemeleri ile ilk büyük farkındalığı yaratmıştır (Ullrich, 2007:9-10). Kuşkusuz bu yılların radikal dönüşümlere hazır olan sosyo-politik ruhu ve yeniden örgütlenen sanat mekanları, farklı disiplinlerden gelen sanatçıları çağdaş sanat mekanlarında bir araya getirmeyi başarabilmiştir.

1960'Iı yıllardan itibaren, MoMA küratörü Mildred Constantine ve tekstil tasarımcısı Jack Lenor Larsen, bir dizi kavramsal ve teknik parametre belirleyerek, lifin modern sanat dünyasındaki itibarını iyileştirmek için "mesleğin ötesinde" bir statüye sahip sergiler açmıştır. Bu sergilerle büyük zanaat ve sanayi derneklerinde çalışan sanatçıların eserleri ile eleştirel beğeni toplayan bir grup avangart arasındaki maddi ve biçimsel bağlantılar vurgulanmıştır (Eager, 2015:251).

Mildred Constantine 1969 yılında modern sanatın en saygın sergi alanı olan MoMA'da Wall Hangings başlıklı uluslararası sergiyi düzenlemiştir. Üç farklı kuşaktan yirmi sekiz dokuma sanatçısını içeren sergi; Bauhaus ekolü sanatçılar, II. Dünya Savaşı sonrasında Avrupa'da doğan sanatçılar ve Amerika'daki itibarlı tasarım programlarında okumuş Amerikalı sanatçılardan oluşmaktadır. Jagoda Buic ve Magdalena Abakanowicz gibi sanatçıların yer aldığı bu sergi; yün, sisal, at kılı ve paçavraları iplik yaparak duvara değil ortaya asılan, boşlukta izleyiciyle her açıdan iletişim kuran devasa üç boyutlu çalışmalar ile öncü bir nitelik taşımıştır (Acar, 2013:54), (Görsel 1). 


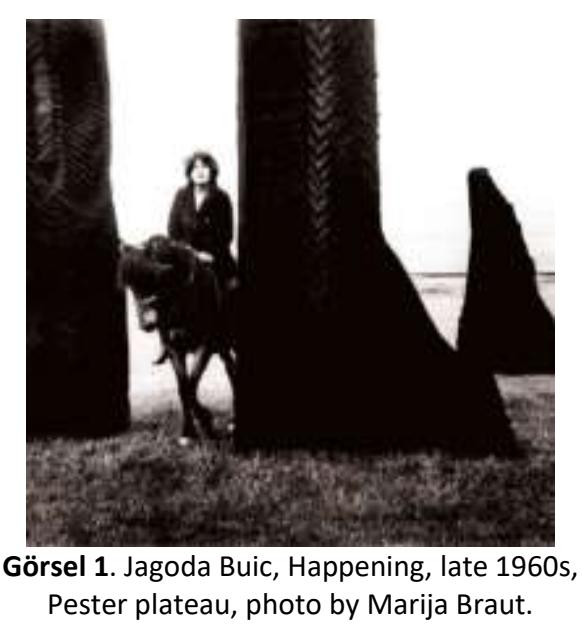

Öte yandan lif sanatı aynı yıllarda gelişen süreç ve çevre sanatının içinde yer alan kavramsal sanatçılar tarafından da yeni bir ifade biçimi olarak kullanılmıştır.

Özellikle 1970 sonrası gelişen feminist sanat pratiklerinde, el sanatlarının kadın işi olarak görülmesine tepki şeklinde gelişen uygulamalar, tekstil sanatının feminist sanatın önemli bir temsil aracı olarak da kullanılmasına yol açmıştır. Judy Chicago, "The Dinner Party" enstalasyonunda geleneksel olarak kadını simgeleyen üçgen şeklinde düzenlenmiş devasa masaya yerleştirilen dantel örtüler örneğinde olduğu gibi tekstilin her türlü malzeme ve mekansal kullanımını geleneksel kadın imajına bir gönderme olarak araçsallaştırmıştır.

Miriam Schapiro, 70'li yılların sonlarında birçok kadın sanatçıyla birlikte, buluntu kumaş parçaları ve akrilik boya ile oluşturduğu kolaj-resimler ile dikkat çekmiştir. Dönemin feminist terminolojisi içinde, kadınların kendileri ile özdeşleştirilen malzeme ve teknikleri kullanarak yaptıkları kolajlar famaj olarak nitelendirilmiştir (Ersen, 2010:74). Bu çalışmalar, kadın ile özdeşleşen tekstil malzemeleri ve tekniklerini (kumaş, tül, örme, dokuma v.b) içermeleri açısından önem taşırlar (Görsel 2).

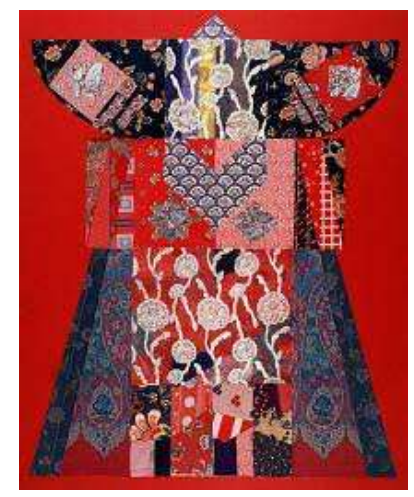

Görsel 2. Miriam Schapiro, Kimona, 1979, Ahşap Üzeri Serigrafi, $172.7 \times 127$ cm. 
$\mathrm{Bu}$ çabalar, 60 sonrası tekstil sanatının, kendi sınırlarını aşmasına, teknik ve malzemenin kavramsal dönüşümüne zemin hazırlamıştır. Bir bakıma her malzeme ile sanat yapma olanağı, lifin, demirin, ahşabın ya da herhangi bir malzemenin ve tekniğin hiç kimsenin ve hiçbir sanat türünün tekelinde olmadığını göstermiştir.

Auther ve String (2010:7) lif sanatının; el sanatları, yerli üretim ve kadın işi ile ilişkisinin bir yan ürünü olan türler hiyerarşisinde uzun süre devam eden durumunun artık yeni bir perspektife sahip olduğunu belirtmektedir. Böylece, Auter (2008:13-14)'in de belirttiği gibi kendini marjinal olarak tanımlayan sanatçılar yolu ile, elyafın sıkışmış sınırlarına yeni ifadeler bulunmuştur. Tekstilde lif sanatı; farklı disiplinlerin buluşması sonucu ortaya çıkan yeni sanatın yeni aracı, karmaşık güç ilişkileri ağı içinde farklı bir konuma sahip olan, birden fazla alandan veya konumdan beslenerek yükselen, yeni sanat nesnesi olarak yeniden yorumlanmıştır.

Lif sanatı artık bilinçli olarak tasarlama eyleminin yapıldığı, endüstri ürünü dışında sanatsal yaratıların ifade bulduğu yeni bir döneme giriş yapmıştır. Böylelikle lif sanatında nesne, fiziksel işlevini yerine getirmesi zorunluluğu ile sıradan, tek düze boyutundan sıyrıımış kapsamı genişleyerek "estetik işlev" adı altında sanatçıya bireysel birikimlerini ortaya koyma olanağı sunmuştur (Önlü, 2004:90).

1960-70'li yıllar tekstil sanatının kendini yeniden farklı anlatım olanaklarıyla var etmeye çalıştığı zorlu yıllar olarak geçerken, devam eden yıllarda tekstil sanatı daha çok postmodern sanatın ilgi alanlarına yönelmiş, malzeme ve teknik güncel kavram ve temsillerin neredeyse bir aracı konumuna gelmiştir.

\section{Güncel Sanatta Tekstil Heykellerin Temsil Niteliği}

Modern sonrası ve postmodern olarak anılan $1980^{\prime} l i$ yıllara gelindiğinde; yıkılan duvarlar, açılan sınırlar, göç, yenidünya savaşları, globalleşme, ekolojik dengelerin bozulması, çok merkezli ve çok kimlikli toplumsal hareketler, cinsiyet, etnisite, coğrafya, beden, internet, aids gibi güncel yaşamın sosyo-ekonomik ve sosyo-kültürel dinamikleri sanatın yeniden yapılanmasını gerekli kılmıştır (Alp, 2016:100-101). Sanatçılar bu toplumsal dinamiklerin getirdiği yeni sorunları siyasal bir eleştiri çerçevesinde ele almaya başlamışlardır. Tekstil malzemeler ile çalışan sanatçılar için de artık güncel sanattaki varoluş sınırı aşıldıktan sonra, malzeme tamamen bir aktarım aracına dönüşsmüştür. Kuspit (2010:31) aktarımı, malzemeyi sanat haline getirmek için gereken duygusal emek olarak 
tanımlamaktadır. Malzemenin bir taraftan kendi kimliğini korurken diğer taraftan bu kimliği araçsallaştırması tekstilin heykele iyice yaklaşmasını sağlamıştır.

Elyafın sahip olduğu yapısal plastik özellikler bile farklılık arayışı içinde olan lif sanatçısına bilinen anlayışın değişmekte olduğunu, sürekli gelişen ve değişen bir eğilime yönelmesi gerektiğinin sinyallerini vermiştir. Böylelikle lif sanatçısı yapıtlarını, yüzeysel veya üç boyutlu yumuşak heykel formları, inter-aktif uygulamalar ve belirli mekânda yerleştirme (enstelasyon) veya giyilebilir giysi düzenlemeleri olarak çeşitlendirmiştir (Arslan, 2012:41).

Malzemeye göre çeşitlenen ve şekil alan bu güncel sanat eserleri, yapısal özelliklerine göre de ayrışmıştır. Tekstil heykeller, üç boyutlu formlarda yapılan ve farklı malzemelerin bir arada kullanılmasına olanak sağlayan ürünlerdir. Bükülebilir malzemelerin tekstil formlarında kullanılması sınırsız ifadeye izin veren dinamik ve etkileyici yapıtların ortaya çıkmasına olanak sağlamaktadır (Udeani, 2014:81). Tekstil malzemesinin bu aktarım gücü, farklı tekniklerle bir araya getirildiğinde elde edilen çok boyutluluk, 70 ve sonrası tekstil malzemesi ile çalışan sanatçıları en çok heykel formlarına yönelmeleri açısından etkilemiştir.

Tekstil heykellerin oluşumuyla birlikte $70^{\prime}$ li yılların ortalarında malzeme seçiminde kökten değişimlerin yaşandığı görülmektedir. Bükülebilir malzeme olan elyaf genellikle iki boyutludur, ancak yaratıcı süreçte üç boyutlu dokuma heykellere dönüştürülerek kullanılmıştır. Tarih öncesi çağlarda kullanılan deri ve keçe yeniden tabaklanmış, lifli malzeme kullanımı çoğalmış, kenevir, sicim, jüt gibi malzemeler, sanatçı dokumacıların kullandığı malzemeler durumuna gelmiş ve iplik veya lif ile bir sanat ekolü oluşturmuştur. Keçe ve kağıt yapımında kullanılan bükülmüş lifler, halatlar, ince bükülmüş iplikler, yeni dokuma akımında "uç malzemeler" haline gelmiştir. Bu yeni tarz, sanat dünyası için özel bir ilgi alanı olmuş duygusal deneyim ve yorumlarla sanat yapıtları haline gelmiştir (Oyman, 2012:6). Özellikle 70 sonrası tekstil malzemeyle çalışan sanatçılar, genel bir belirlemeyle yukarıda söz edilen güncel sanatın belirli ilgi alanlarına yönelmişlerdir. Kadın üzerinden gelişen cinsiyet ve kimlikler, demokrasi-insan hakları ve birey, zaman ve mekan, ekolojik ve çevresel duyarlılık, coğrafya ve öteki gibi kavramlar tekstil malzemesi ile çalışan sanatçıların temel yönelimleri olmuştur. Temelde lif olmak üzere her türlü tekstil malzemesinin yanı sıra, teknolojik bir takım araçları da temsilin bir aracı olarak kullanmışlardır. Toplumsal 
duyarlılık sanatçıları hem sosyal hem de bireysel anlamda güncel sorunların eleştirisine yöneltmiştir.

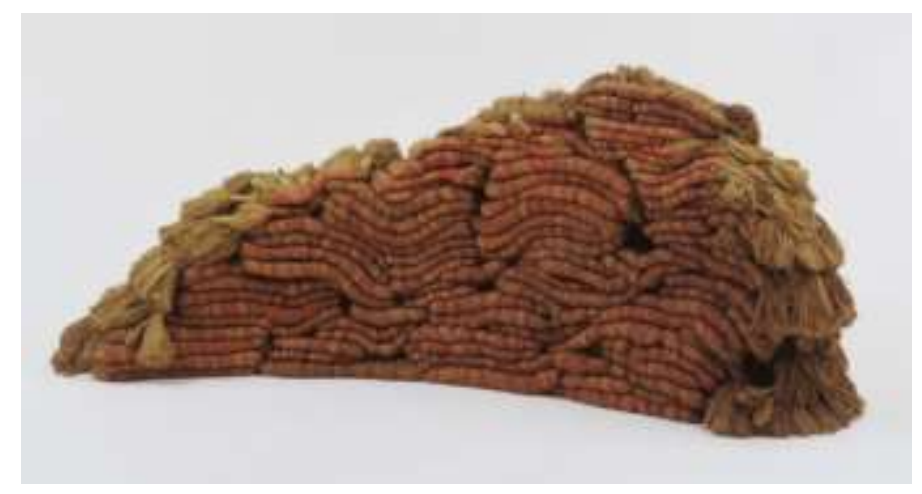

Görsel 3. Sheila Hicks, The Evolving Tapestry, (1967-68), Keten ve ipek, değişken boyutlar, Museum of Modern Art, New York.

Lif sanatçısı Sheila Hicks'in sosyal çatışmalara dikkat çekmek istediği “Gelişen Goblen (1969)" adlı tekstil heykeli sadece tekstilin dokuma özelliğini değil aynı zamanda heykelsi etkilerinin önemini, yapısal rezonansını da dile getirir. Her toplanıp serildiğinde farklı formlar oluşturan eser, kitlesel yığınları ve kolektif hacimleri temsil etmektedir (Fowler, 2014:35), (Görsel 3).

Claire Duchen (1986:10); Hicks'in profesyonel sanatçı statüsünü ve geleneksel anne bakım beklentisini bir araya getirdiği Koruyucu Duvar olarak yinelenen Gelişen Gobleninin Fransa'da 1968'in sonrasında ortaya çıkan Fransız kadın hareketinin tarzını ve içeriğini derinden etkilediğini, 1960'ların radikalizmi ile kadın meseleleri arasındaki ilişkinin dikkate alınmasında öğretici rol üstlendiğini ifade etmiştir. Bir başka söyleyişle eser artık dönemin ideolojik bir duruşu ve toplumsal bir simgesi haline gelmiştir.

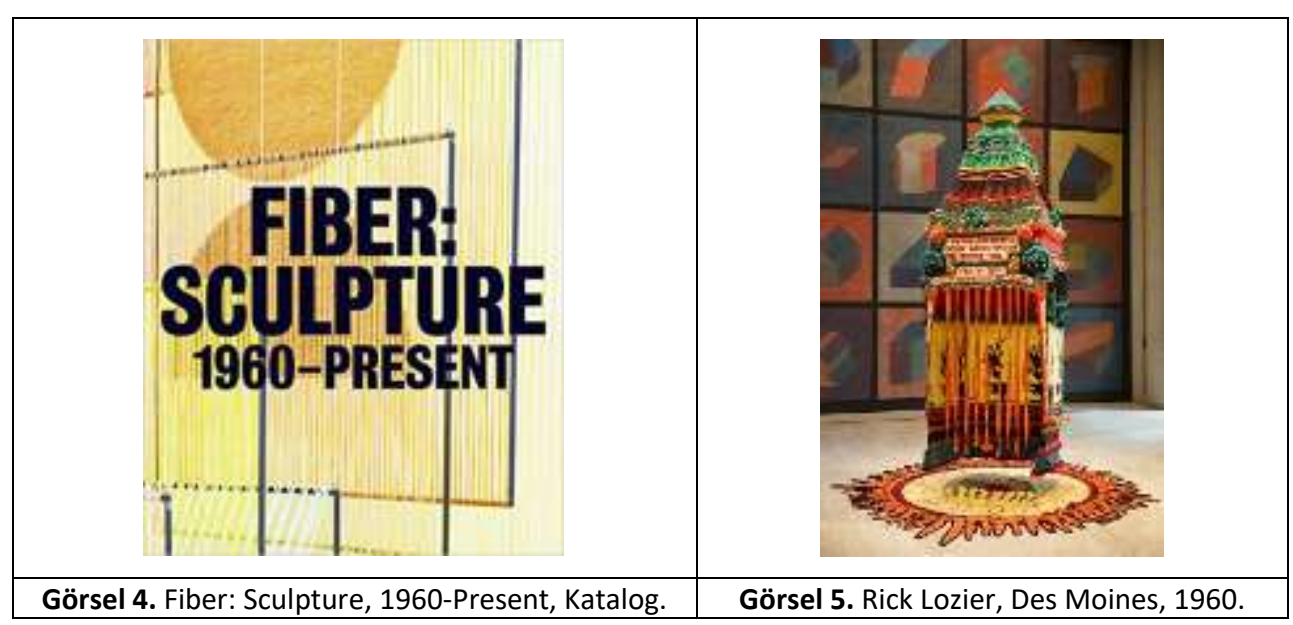


Küratör Jenelle Porter tarafından 2014 yılında organize edilen "Fiber: Sculpture 1960-Present" sergisi, kırk yılı aşkın bir geçmişiyle tekstil heykellerin farklı temsil biçimlerini, farklı teknik ve malzemelerle, zaman mekan etkileşimleri, yapıtın kendi varoluşsal duruşu gibi pek çok sorun ve çözümü yıllar içinde nasıl oluşturduklarını gözler önüne sermesi açısından büyük bir önem taşımaktadır (Görsel 4, Görsel 5).

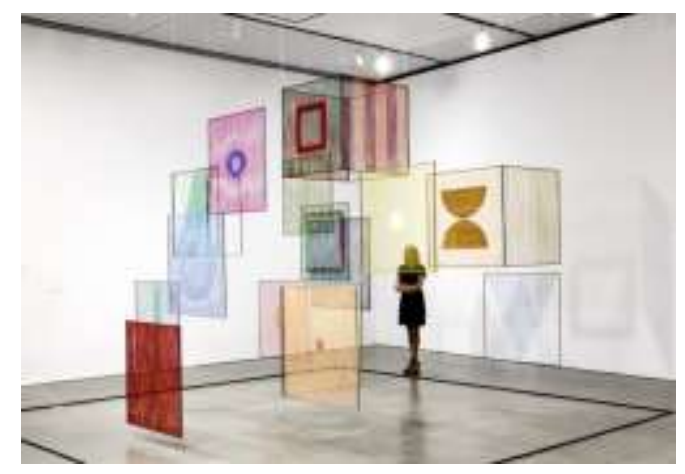

Görsel 6. Fiber: Sculpture 1960-Present.

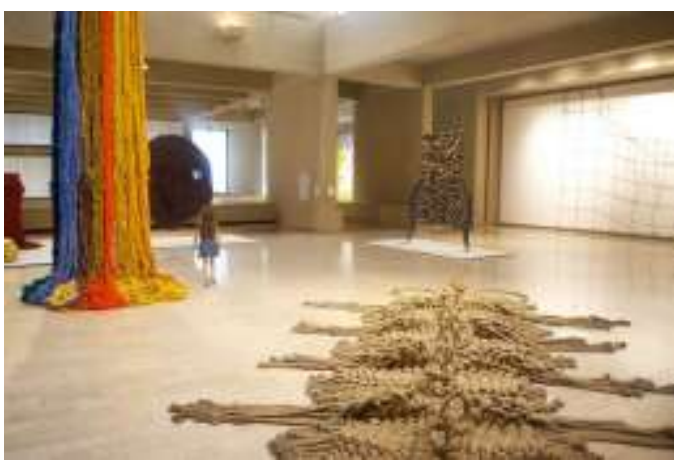

Görsel 7. Fiber: Sculpture 1960-Present.

Jenelle Porter (2014:2), 33 sanatçının katıldığı ve tavan arasında kalan yün, pamuk gibi ipliklerden geleneksel yöntemlerle üretilen eserlerin tabandan duvara aktarılmasıyla hazırlanan "Fiber: Sculpture 1960-Present (Elyaf: Heykel)" isimli sergide, kırk yıldan uzun bir süredir elyaf sanatında soyutlama ve boyutluluğun yirminci yüzyılın ortasından günümüze kadarki gelişimini incelerken; asırlık teknikleri ve geleneksel malzemeleri uyarlayarak liflerle çalışan sanatçıların malzemenin sonsuz dönüşümlerini göstermek için yerçekimi, ışık, renk, kütle ve şeffafığı manipüle ederek kullandıklarını göstermiştir. Bu geniş kapsamlı sergiden çıkarılacak sonuç ise, artık elyafın çağdaş sanat söylemine katkıda bulunup bulunamayacağı değil, bunu nasıl yaptığıdır (Porter, 2014:2), (Görsel 6, Görsel 7).

Güncel sanatın önemli bir ilgi alanı olan zaman ve mekan kavramları, tekstil malzemesi ile çalışan sanatçıların, geçmiş ve bugün arasındaki ilişkileri, sınır, geçişkenlik, varlık-yokluk gibi dualiteleri, zaman-mekan kavramları etrafında yeniden araştırmalarına dayanır. 


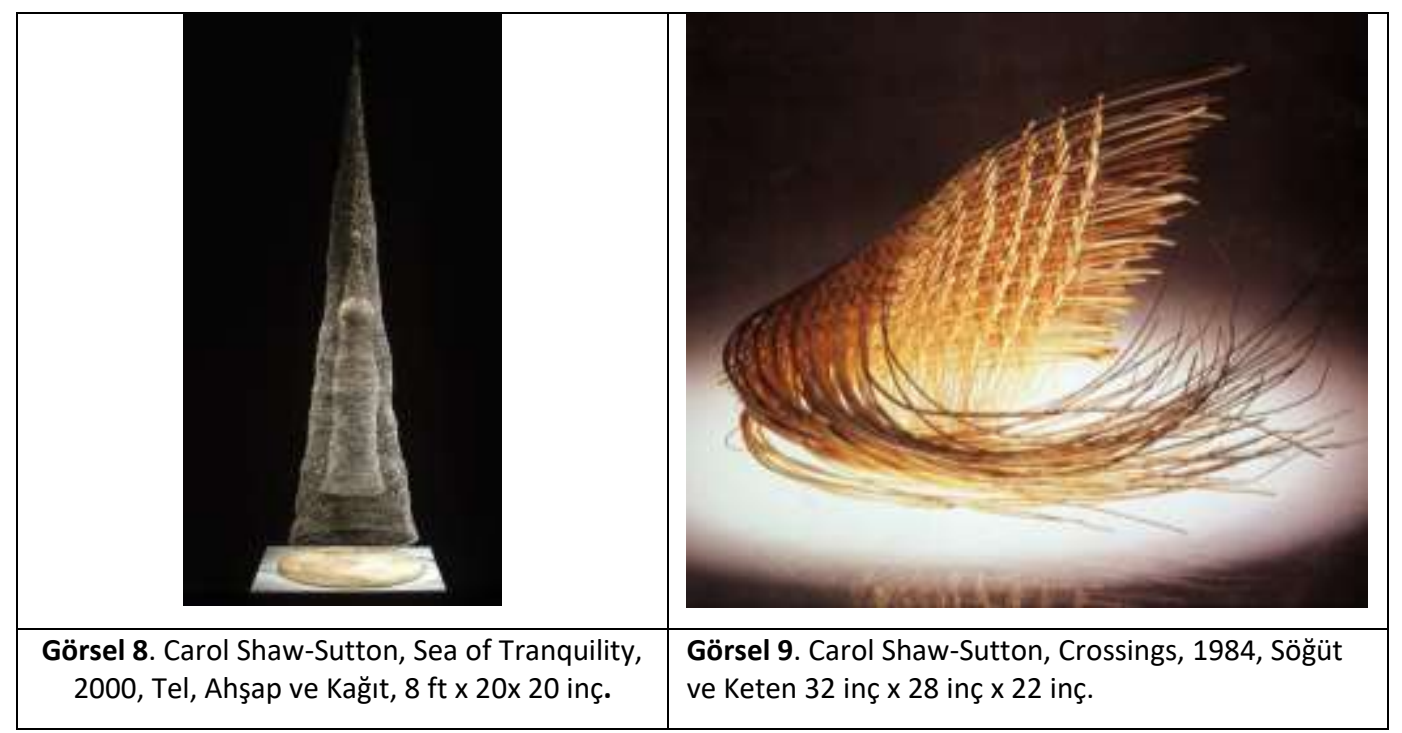

California State Üniversitesi'nde elyaf ve tekstil işlemlerinde uzmanlaşmış bir heykeltıraş ve montaj sanatçısı olan sanat profesörü Carol Shaw-Sutton eserlerinde; geleneksel yöntemlerin biçim ve konsepti ile birlikte modern tekstil tekniklerini kullanarak özgün formlar oluşturmuş ve aynı anda zaman ve mekan kavramlarını aşmayı amaçlamıştır. Insan kaygı ve duygularını aktarırken görsel ve şiirsel odak noktaları yakalayarak empati kurmuş, geçmiş, özlem, yolculuk, yara izi, tamir, bakım, geçiş gibi duyguları tekrarlayan tekstil heykeller yaratmıştır. Sanatçının üç boyutlu tekstil heykelleri doğal malzemelerin benzer birim ve parçalarının tekrar edilmesi ile elde edilmiş yapıtlardır (Özcan, 2017:126127), (Görsel 8, Görsel 9).

Güncel sanatta beden çeşitli uygulamalara konu olan başlı başına bir alandır. 1960’।ı yıllarla başlayan bedene ilişkin pratikler genellikle, uygarlaşmış ve doğal beden ile özel ve kamusal alana ait beden arsındaki güç çekişmelerine vurgu yapar (Alp, 2014:344-348). Beden aynı zamanda psikanalitik bir çözümlemenin de öznesi durumundadır. Özellikle çıplak beden kamusal alana açıldığında güç, iktidar, acı, şiddet, cinsellik, cinsiyet, kimlik gibi alanların sorgulandığı bir platforma dönüşür. Tekstil sanatçısı Lorenzi Nanni, beden ve bedenin çeşitli parçaları ile entegre ettiği tekstil malzemelerini, insana ait farklı duygulanımları aktarmada kullanmıştır. 


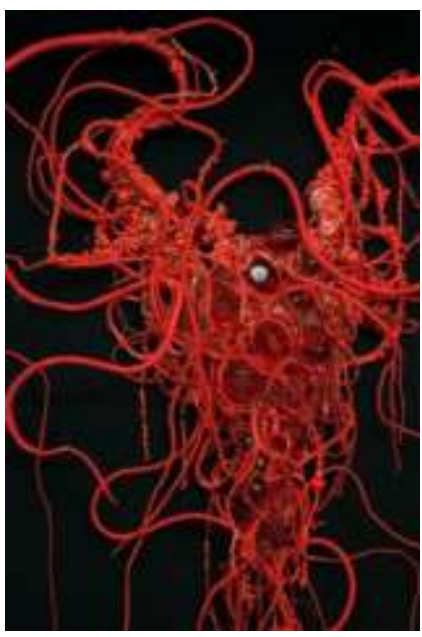

Görsel 10. Lorenzi Nanni, Haemorrhagia, $50 \times 39 \mathrm{~cm}$.

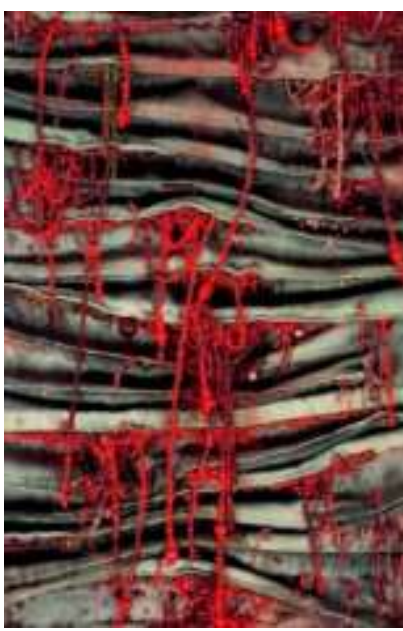

Görsel 11. Lorenzi Nanni, 75011, 2004, 50×39 cm.

Fransa'da sanat eğitimi alan Lorenzi Nanni, tekstil tasarımı ve nakış-işleme tekniklerini incelemek için Paris'e gelerek eğitimine Duperre Art School'da devam etmiştir. Canlı organizmaları araştıran sanatçı, organik objelerin karakteristik özelliklerini irdeleyerek ipeği ve keçeyi şekillendirmiş, boncuk işleme, nakış ve süsleme tekniklerinden yararlanarak tekstil heykellerine nefes aldırmıştır. Genellikle doğal başlangıç noktalarından yola çıkan sanatçı, hayvan eti, bağırsak, saç, kan, damar ve bitki dokusu formlarını kullanarak "uğursuz" olarak nitelendirdiği üç boyutlu heykelsi parçalar ve protez takılar yapmıştır (Görsel 10, Görsel 11).

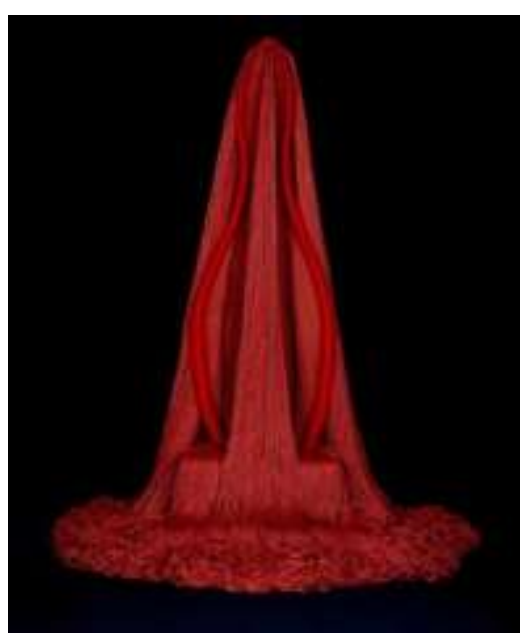

Görsel 12. Claire Zeisler, Red Preview, 1969, a fiber construction.

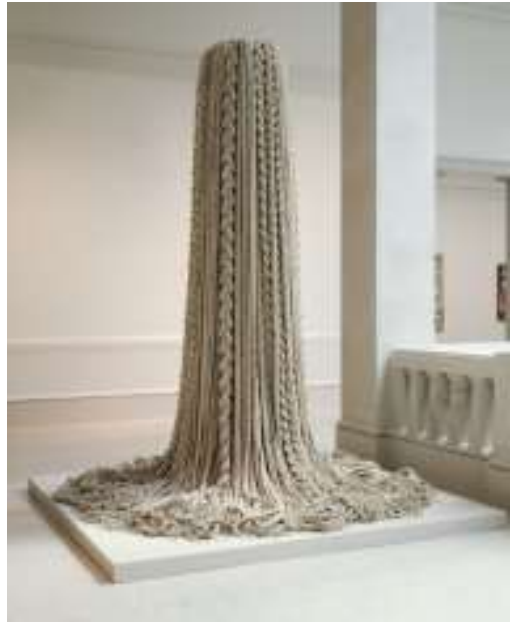

Görsel 13. Claire Zeisler, Private Affair I, 1986.

Bir başka lif sanatçısı Zeisler, 60'lı yıllardan itibaren kadına vurgu yapan, cinsellik ve fallik olarak adlandırılan renk ve biçim simgeleriyle soyut heykeller tasarlamıştır. 
Amerikalı lif sanatçısı Claire Zeisler; heykeltıraş ve ressam olarak eğitim almıştır. Feminist sanatçılar içerisinde gösterilen Zeisler kariyeri boyunca elyaf ile "büyük, güçlü, üç boyutlu tek görüntüler" yaratmaya çalışmış ve müstakil heykellerin ifade niteliklerinin genişletilmesine öncü olmuştur. Doğal maddelerle çalışmayı tercih eden Zeisler lif, jüt, rafya, yün, sisal, deri, kenevir gibi maddeleri doğal renkleriyle kullansa da renklendirmek isteği lifleri kadınlığı temsil eden "doğal kırmızı" renkle boyadıktan sonra eserlerini oluşturmuştur (Thurman, 1979:8-9), (Görsel 12, Görsel 13).

Dokumada öncü ve yenilikçi dört kadın sanatçı ile çalıştığı üç boyutlu örgü heykelleriyle avangart sanat akımları içerisinde karşılığını bulamayan Zeisler, koleksiyonunu “Woven Forms" olarak adlandırmış ve 1963'te New York'taki Çağdaş El Sanatları Müzesinde sergilemiştir. Çalışmalarını farklı formlara taşımak isteyen Zeisler, gemiciler tarafından kullanılan düğüm tekniğini iki boyutlu ve geometrik limitlerinden uzaklaştırarak üç boyutlu işlere dönüştürmüş ve böylelikle 96 inçlik sıkı düğümlü ve serbest düşüşlerle oluşturulmuş ayakta duran heykeller yaratmıştır (Constantine ve Jack, 1981:18). Sanatçı, fonksiyonları olmayan üç boyutlu heykelsi yapıtlarında, geleneksel dokuma tekniklerinden düğüm oluşturma, sarma ve dikiş oluşturma tekniklerini kullanarak avangart sanatçılara ilham kaynağı olmuştur (Özcan, 2017:113; Darrel, Barsky ve Leigh, 1991:26).

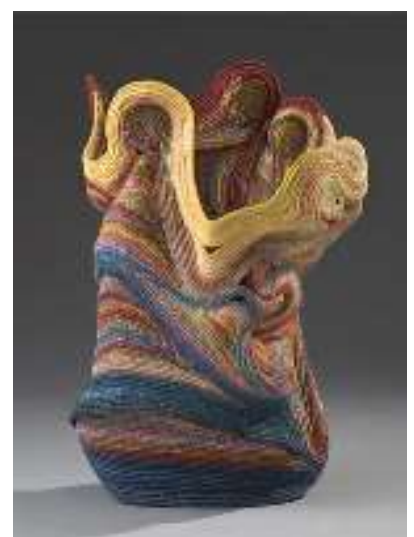

Görsel 14. Ferne Jacobs, Floating World, 2007.

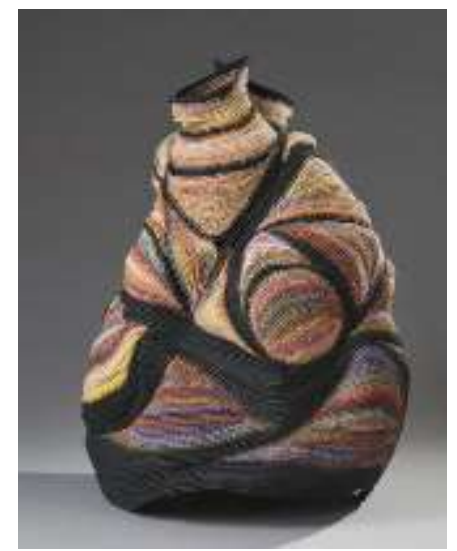

Görsel 15. Ferne Jacobs, The Round, 2007.

Güncel sanatın biçimsel ya da kavramsal eklektik yapılara yaptığı gönderme, geleneksel bir form olan sepeti güncel soyut renk ve formlarla bir araya getiren Chicago doğumlu heykeltıraş ve lif sanatçısı olan Ferne Jacobs, California'da sanat ve zanaat eğitimi almıştır. Çağdaş renkleri ve geleneksel olmayan formları, eski sepet dokuma teknikleri olan 
düğümleme ve bükme teknikleri ile birleştirerek çağdaş sepetler yapmıştır. Bu yapıtlar artık bir sepet olmaktan çıkıp soyut birer heykel olarak değerlendirilebilir hale gelmiştir.

Yapıtlarında mumlu keten halatlar kullanan sanatçı, "Sculpture in Fiber (Elyaf Heykel)" Denver Sanat Müzesi, Colorado (1972), "In Praise of Hands (Ellerin Övgüsü)” Çağdaş El Sanatları Müzesi, New York (1972) gibi eserleriyle galerilerde özel ve genel kalıcı koleksiyonlar sergilemiştir. Sepetlere yeni bakış açısı getiren sanatçı üç boyutlu formlarda heykel tekstiller üretmiştir (Heller and Heller, 2013:281), (Görsel 14, Görsel 15).

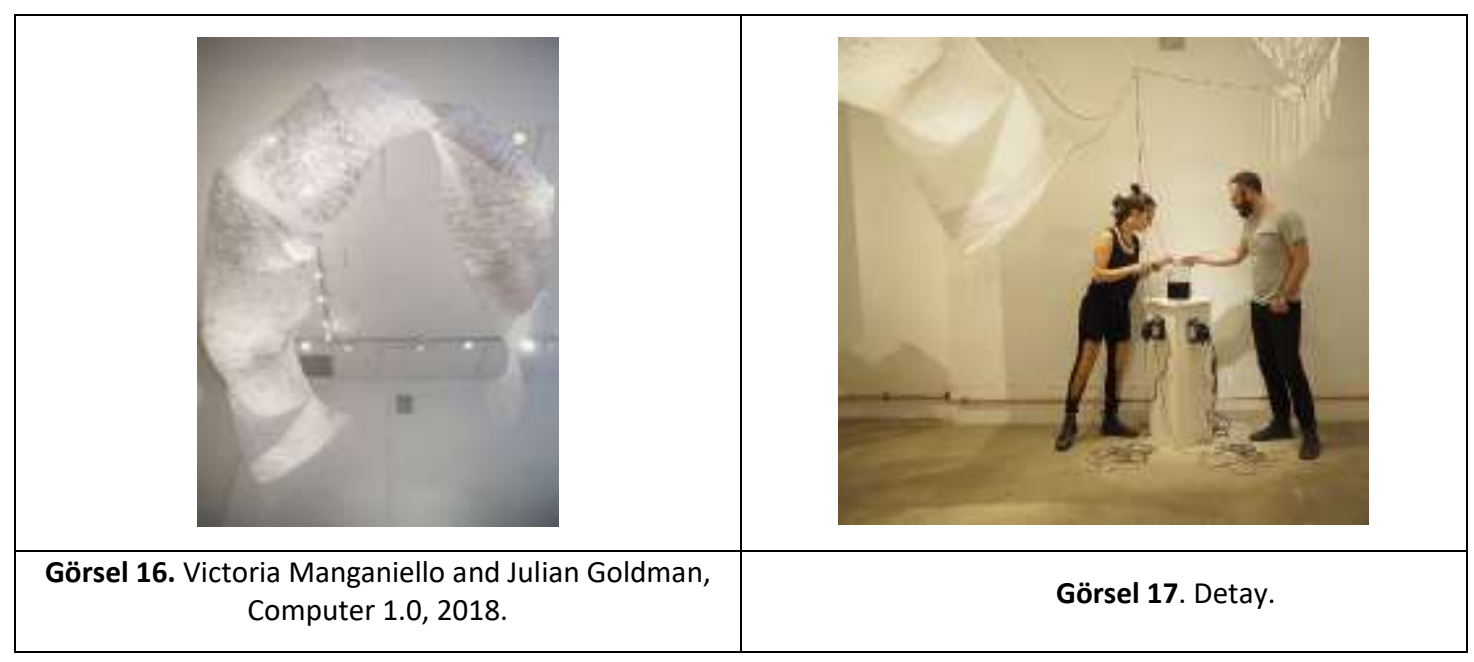

Teknoloji ve güncel sanatın birlikteliğiyle ortaya konulan “Computer 1.0", kırık teknolojik çöp devrelerinin görünmez varlığının hayat bulduğu, canlı, çevre ile etkileşime giren bir yapıt olarak tekstil heykeller arasında yerini almıştır. Tekstil sanatçısı Victoria Manganiello ve bilgisayar mühendisi Julian Goldman'ın bu tasarımı ile; ipek dokuma ustası Joseph Maria Jacquard tarafından 1801 yılında Paris Sanayi Sergisinde sergilenen mekanik tezgahla dokunan esere atıf yapılarak, veri akış ve kodlarının, bilgi alış-verişinin ve iletişim ağlarının ilkel yapısı ortaya konulmuştur. Bu ağların temsili olan borular içerisinden belirli kod ve sıralamayla veri akışının yapıldığını simgeleyen ve madde hareketini sağlayan aktif heykel, tekstil nesnesi olmanın dışında farklı form ve amaçla sahnedeki yerini almıştır. Sanatçı Victoria Manganiello "jakarlı dokuma tezgahı bir kalıntı değil ilk bilgisayarımız olan Adem ve Havva'nın modern bilgisayarlarıdı" diyerek eserin dijital platformdaki yerine dikkat çekmiştir (Görsel 16, Görsel 17). 


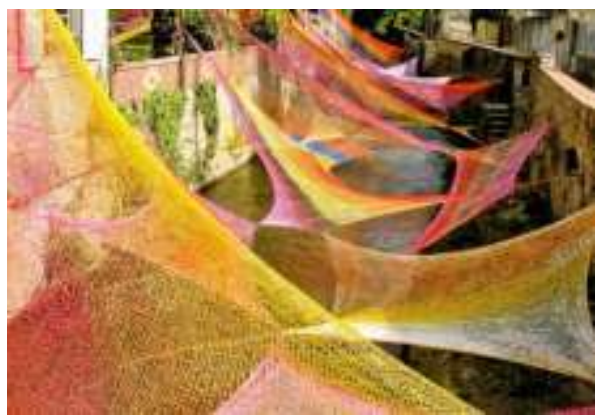

Görsel 18. Edith Meusnier, Sur Le Theme De L'eau Et Du Feu, 2010.

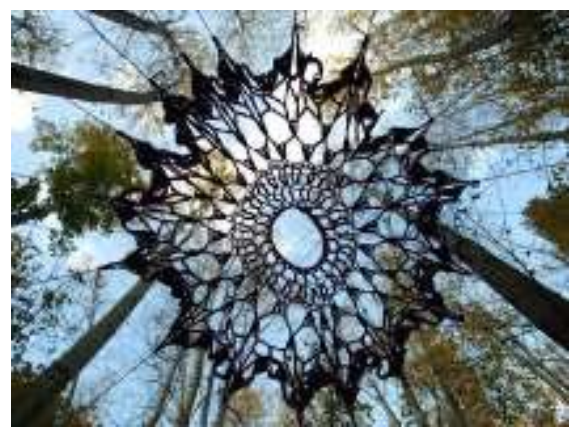

Görsel 19. Atefeh Khas, Freesler Dreams, 2010.

Tekstilin güçlü yapısal özelliklerinin farkında olan, değişim için savaşan ve çevre sorunlarına farkındalık yaratmak adına faaliyet gösteren çevre sanatçıları da güncel sanattan beslenerek tekstil nesnesini amacı dışında yorumlayan sanatçılar arasında yer almışlardır. Yarattıkları tekstil heykellerle sadece çevreye dikkat çekmemiş sürdürülebilirlik, geri dönüşüm, doğa-insan etkileşimi ve yaşayan doğa olaylarını tanımlayacak hareketlerde bulunmuşlardır. Genellikle atık malzeme veya geri dönüşümden elde edilen tekstil malzemelerle eserlerini oluşturan sanatçılar, tüketim kültürünü açığa vurmak, hasarlı ortamları düzeltmek ve doğadakileri doğadakilere vermek amacı ile hareket etmiş, kamusal alanda oluşturdukları enstalasyonlarıyla dikkat çekmişlerdir (Resim 18, Resim 19).

\section{Sonuç}

1914'de Dadacıların ve Duchamp'nın, çağdaş avangartlardan önce, hazır yapım nesneleri sanat nesnesi olarak lanse etmeleri, sanat nesnesinin, sanatçının ve sergi mekanının statüsüne ilişkin ilk öncü uygulamaları gündeme getirmiştir. 1960'lı yıllar ise yeni toplumsal dinamiklerin etkisi ile sanat olgusunu oluşturan tüm dinamiklerin temelden dönüşümüne tanıklık eden yıllardır. En genel anlamıyla; sanatın yaşamdan koparak kurumsallaşması, temsil niteliğindeki biçimselliğin kavramsal olanı sınırlaması, bilim, teknik ve kuramsal çalışmaların yol açtığı yeni yaklaşımlar, sanatçıların yeni temsil olanaklarını araştırmalarına olanak sağlamıştır. Bu yeni temsil anlayışı, malzeme, teknik ve aktarım olanaklarının sınırlarını modernizmin katı biçimciliğinden ve en önemlisi sanat türlerinin disipliner sınırlarından kurtarmıştır. Bu yeni yönelim, her sanat disiplininin ve modernitede zanaat olarak kabul edilen disiplinlerin de kendi alanlarını terk etmelerine ve disiplinlerarası yeni bir senteze gitmelerine yol açmıştır. $60^{\prime}$ Iı yılların bu atmosferi geleneksel sanatlar genel başlığı altında kategorize edilebilecek tekstil sanatının; yeni malzeme, teknik ve yeni anlatım (enstalasyon, heykel vb.) olanaklarını araştırmasına olanak sağlamıştır. 
Avrupa'da sanayi toplumunun örgütlenmesine özgü; endüstrileşme, hızlı kentleşme, köyden kente göç, el sanatlarının yok olmaya başlaması gibi dinamikler yüzyılın başında sanatçıları, zanaat-sanat ve endüstri ortaklığındaki arayışlara itmiştir. Endüstrinin devasa gelişimi salt el sanatlarına değil, sanat disiplinlerinin de yok olmasına bir tehdit oluşturmuştur. Bu bakımdan tekstil teknik yönüyle endüstriye bağlanırken diğer taraftan zanaat olarak ve sanatın bir yan malzemesi olarak da işlevini sürdürmüştür. Tekstilin sanat ile entegre edilmesindeki ilk akademik çabaların Bauhaus Okulu ile olduğu söylenebilir. Bauhaus'un zanaat ve sanatı estetik bir bütünlük içinde ele alınması anlayışına dayanan bu bütüncül yaklaşımı, daha sonradan tekstilin sanat olarak kabul edilmesindeki rolü üstlenecek sanatçıları yetiştirmesi tekstil sanatının tarihi açısından önemli olmuştur. Ancak tekstilin, zanaat olarak yerleşmiş konumu 1960 '। yılların kavramsal çalışmaları ile birlikte dönüşmeye başlamıştır.

1960 ve 70 'li yıllar tekstil sanatçılarının teknik ve malzemede yapısal çözümleri en yoğun şekilde araştırdıkları yıllar olmakla birlikte, tekstilin kavramsal ve felsefi boyutlarıyla da dönemin sanatına katıldığı yıllardır. Tekstil sanatı bu yıllarda genel olarak, tekstil disiplininden gelen sanatçıların yanı sıra, kavramsal ve minimalist sanatçıların da tekstil malzemelerini sanat pratiklerinde ve enstalasyonlarında kullanmaya başladıkları yıllardır. Özellikle lifin yapısal özellikleri, doğal ve insani boyutu, tekniğe göre değişen yumuşak ve sert dokusu, kolay şekil alabilen özelliği, diğer malzemelerle olan estetik ilişkisi önemli bir aktarım ve temsil aracı olarak kullanılmasının temel nedenleri olmuştur. Öte yandan 1970'lerde yükselen feminist sanat uygulamaları, tekstilin "kadın işi" olarak imlenen konumunu eleştirel ve kavramsal düzeyde ele almış ve bu çabalar tekstilin sanatta yeni bir temsil alanı olarak yer bulmasında etkili olmuştur. Aynı yıllarda açılan geniş kapsamlı ve çoğul söylemlere imkan veren sergiler, tekstil sanatçılarının yıllarca süren çaba ve araştırmalarının çarpıcı örneklerini açığa çıkarmıştır.

1980 'lerde ise elyaf, sanat nesnesinin bir aktarım aracı olarak malzeme ve tekniği aşmış, mekanın yeni bir öznesi olarak ayağa kalkmıştır. Tekstil heykellerin temel unsuru olan elyaf, güncel sanat ekseninde iki boyutlu yapısından uzaklaşarak üçüncü boyutunun keşfi ile birlikte yer aldığı ortamda kendine bağımsız bir hareket alanı bulmuştur. Elyafın güncel sanatın içerisinde yer almasına olanak sunan bu üç boyutlu yapısı, form, biçim, doku, strüktür gibi heykel sanatının temel unsurlarıyla yeniden yorumlanarak zeminden 
kopmasına ve ayakta durmasına olanak tanımıştır. 1980'lerin küreselleşen dünyasında ötekileştirmeyi sorunsallaştıran postmodern bir sanat anlayışının, bundan böyle hiçbir malzeme, teknik ve kurguyu ötelemeyeceği açıktır. Bu açılım ve sınırın yıkılması ile bu yıllarda öne çıkan kimlik, cinsiyet, etnisite, savaş, göç, ekolojik dengeler, demokrasi, birey, beden, mekan ve yeni teknolojiler gibi kavramlar ve temsil alanları tekstil heykellerin tam olarak varlık kazandığı yıllardır.

1970'li yıllardan itibaren kimi sanatçılar, tekstil heykelleri sosyo-politik, kültürel ve eleştirel bir zeminde kurgulamışlardır. Öte yandan, mekan ve heykel, boşluk-doluluk, ışıkkütle, geçişkenlik ve sınırlar, beden ve organizma, zaman, gelenek ve güncel, malzeme-işlev ve estetik, cinsiyet, ekoloji ve geri dönüşüm, teknolojik sınırlar gibi güncel kavramlar tekstil sanatçılarının da heykellerinde en önemli temsil alanlarını oluşturmuştur.

\section{Kaynakça}

Acar, S. (2013). "Tapestry Geleneğinden Lif Sanatına Geçiş Sürecinde Jagoda Buic ve Sanatsal Çalışmaları", Yedi: Sanat Tasarım ve Bilim Dergisi, İzmir: Dokuz Eylül Üniversitesi Güzel Sanatlar Fakültesi Yayınları, Sayı 9, s.51-59.

Akay, A. (2010). Birleşmeyen Sentez, İstanbul: Yapı Kredi Yayınları.

Alp, K. Ö., (2014). "Feminist Sanatta Beden ve Yabancılaşma", Süleymen Demirel Üniversitesi Güzel Sanatlar Fakültesi Dergisi ART-E, Sayı 14, s.338-365.

Alp, K.Ö. (2016). "ilişkisel Estetik ve Kamusal Alan Bağlamında Sanatta Yeni Arayışlar”, Yedi: Sanat Tasarım ve Bilim Dergisi, İzmir: Dokuz Eylül Üniversitesi Güzel Sanatlar Fakültesi Yayınları, Sayı 16, s.99-109.

Alpan, D. (1986). "Tekstilde Sanat Objeleri”, 3. Ulusal Tekstil Sempozyumu, 4-7 Kasım, Bursa.

Arabalı, K. S. T. (2017). “Çağdaş Sanat Disiplinleri Arası Etkileşimlerde Lif Sanatı”, idil Sanat ve Dil Dergisi, 6(35), s.2035-2059.

Arslan, C. (2012). "Kamusal Alanda Lif Sanatları”, Akdeniz Sanat Dergisi, 4(7), s.40-43.

Auther, E. (2008). Fiber Art and the Hierarchy of Art and Craft, 1960-80, The Journal of Modern Craft, 1:1, p.13-33, DOI: 10.2752/174967708783389896.

Auther, E. and String, F. (2010). Thread: The Hierarchy of Art and Craft in American Art, Minneapolis: University of Minnesota Publising.

Bakare, O. O., and Bako, W. G. (2016). "Woven Sculptural Piece as Added Dimension to Textile Design", Journal of African Studies, 5(2), p.123-138. 
Barnard, M. (2002). Sanat, Tasarım ve Görsel Kültür, (çev.) Güliz Korkmaz, Ankara: Ütopya Yayınları.

Best, S., Douglas, K. (2011). Postmodern Teori, 2. Basım, (çev.) Mehmet Küçük, İstanbul: Ayrıntı Yayınları.

Braddock, S. E. and O'Mahony, M. (1997). Techno Textiles, 1. Edition, New York: Thames and Hudson.

Bürger, P. (2014). Avangard Kuramı, Sunuş: Ali Artun, (çev.) Erol Özbek, İstanbul: Illetişim Yayınları.

Constantine, M. and Jack, L., (1981). The Art Fabric: Mainstream, Van Nostrand Reinhold, New York.

Darrel, S. Ivy, B. and Leigh, M. K. (1991). "Contemporary American Crafts", Philadelphia Museum of Art Bulletin, 87(372).

Duchen, C. (1986). Feminism in France: From May'68 to Mitterand, Capter 6, London: Routledge.

Eager, E. B. (2015). "Fiber: Sculpture 1960-Present", The Journal of Modern Craft, 8(2), p.251-258, DOI: 10.1080/17496772.2015.1057409.

Ersen, N. L. (2010). “Feminist Sanatın Kadın Sanatçılara Etkisi: Miriam Schapiro, Tracey Emin ve Andrea Dezsö Örnekleri Üzerinden Kadın Zanaatı/Sanatı", Yedi Sanat Tasarım ve Bilim Dergisi, İzmir: Dokuz Eylül Üniversitesi Güzel Sanatlar Fakültesi Yayınları, Sayı 4, s.73-78.

Farago, F. (2006). Sanat, (çev.) Özcan Doğan, Ankara: Doğu-Batı Yayınları.

Featherstone, M. (2005). Postmodernizm ve Tüketim Kültürü, (çev.) Mehmet Küçük, İstanbul: Ayrıntı Yayınları.

Fowler, C. (2014). "A Sign of the Times: Sheila Hicks, the Fiber Arts Movement, and the Language of Liberation", The Journal of Modern Craft, 7(1), p.33-51.

Gürcüm, B. H. ve Kartal, S. (2017). "Bauhaus ile Tasarıma Dönüşen Zanaat", Idil Dergisi, 6(34), s.1767-1798.

Heller, J. and Heller, N. G. (2013). North American Women Artists of The Twentieth Century. A Biographical Dictionary, New York London: Routledge Taylor and Francis Group, ISBN 9781315051680.

Jameson, F. (2011). Postmodernizm ya da Geç Kapitalizmin Kültürel Mantığı, çev. Nuri Pülümer ve Abdülkadir Gölcü, Ankara: Nirengi Kitap.

Kuspit, D. (2010). Sanatın Sonu, çev. Yasemin Tezgiden, İstanbul: Metis Yayıncılık. Lyotard, J. F. (1994). Postmodern Durum, (çev.) Ahmet Çiğdem, Ankara: Vadi Yayınları. 
Oyman, R. (2013). "Lif Sanatında Doğal Malzeme Kullanımı ve Çevresel Sanat Ürünleri", Akdeniz Sanat Dergisi, 4(8), s.4-8.

Önlü, N. (2004). "Tasarımda Yaratıcılık ve İşlevsellik Tekstil Tasarımındaki Konumu”, Atatürk Üniversitesi Sosyal Bilimler Enstitüsü Dergisi, Yıl: 4, 3(1), s.85-95.

Özcan, N. (2017). "Fütürizm ve Çit Örücülügünün Tekstil Tasarımında Tekstür, Strüktür ve Form Oluşumuna Etkileri”, Yüksek Lisans Tezi, Gazi Üniversitesi Güzel Sanatlar Enstitüsü, Ankara.

Porter, J. (2014). Fiber: Sculpture 1960-Present, Boston: Institute for Contemporary Art Publising.

Şaylan, G. (2009). Postmodernizm, 4. Baskı, Ankara: İmge Kitabevi.

Tapies, A. (2014). Sanat Pratiği, (çev.) İsmet Birkan, Ankara: Dost Yayınları.

Thurman, C. M. (1979). Claire Zeisler: A Retrospective, Chicago: The Art Institute of Chicago Publising.

Udeani, N. A. (2014). "Synergy of Uli symbols and textiles: An exploration in textile sculptural forms", Mgbakoigba: Journal of African Studies, 3(1).

Ullrich, P. (2007). Material Difference: Soft Sculpture and Wall Works. Western Springs: Friends of Fiber Art International.

Whitham, G. Ve Pooke, G. (2013). Çağdaş Sanatı Anlamak, (çev.) Tufan Göbekçin, İstanbul: Optimist Kitap.

Yaşar, N. (2019). "Bauhaus'dan Black Mountain Kolejine Anni Albers Dokumaları", The Journal of Social Sciences Institute, Sayı 44, s.131-152.

Yılmaz, M. (2006). Modernizmden Postmodernizme Sanat, Ankara: Ütopya Yayınları.

\section{Görsel Kaynaklar}

Görsel 1. Jagoda Buic, Happening, late 1960s, Pester plateau. Photo by Marija Braut. https://www.richardsaltoun.com/artists/279-jagoda-buic/biography/, Erişim tarihi: 02.02.2020.

Görsel 2. Miriam Schapiro, Kimona, 1979, Silkscreen mounted on wooden dowels. $172.7 \times 127 \mathrm{~cm}$. https://www.slideshare.net/mjarry/miriamschapiro, Erişim tarihi: 02.02.2020.

Görsel 3. Sheila Hicks, The Evolving Tapestry, (1967-68), Keten ve ipek, değişken boyutlar. Museum of Modern Art, New York. (Fowler, 2014:35).https://www.moma.org/collection/ works/3819, Erişim tarihi: 04.01.2020.

Görsel 4. Fiber: Sculpture, 1960-Present, Katalog. https://www.amazon.com/FiberSculpture-1960-Present-Jenelle Porter/dp/3791353829, Erişim tarihi: 12.12.2019. 
Görsel 5. Rick Lozier, Des Moines, 1960. https://www.desmoinesartcenter.org/ exhibitions/fiber, Erişim tarihi:12.12.2019.

Görsel 6. Fiber: Sculpture 1960-Present. https://www.icaboston.org/exhibitions /fibersculpture-1960\%E2\%80\%93present, Erişim tarihi: 02.02.2020.

Görsel 7. Fiber: Sculpture 1960-Present. https://www.newartexaminer.net/fiber-sculpture1960-present/_Erişim tarihi: 02.02.2020.

Görsel 8. Carol Shaw-Sutton, Sea of Tranquility, 2000, Wire, wood, paper $8 \mathrm{ft} \times 20$ in $\times 20$ in. http://www.carolshawsutton.com/work/index.htm, Erişim tarihi: 12.12.2019.

Görsel 9. Carol Shaw-Sutton, Crossings, 1984, Willow, linen 32 in x 28 in x 22 in. http://www.carolshawsutton.com/work/index.htm, Erişim tarihi: 12.12.2019.

Görsel 10. Lorenzi Nanni, Haemorrhagia, 2005, $50 \times 39$ cm. http://www.lorenzonanni.com/, Erişim tarihi: 04.01.2020.

Görsel 11. Lorenzi Nanni, 75011, 2004. http://www.lorenzonanni.com/, Erişim tarihi: 04.01.2020.

Görsel 12. Claire Zeisler, Red Preview,1969, a fiber construction, https://www.wikizeroo. org/index.php?q=aHR0cHM6Ly9lbi53aWtpcGVkaWEub3JnL3dpa2kvQ2xhaXJIX1plaXNsZXI, Erişim tarihi: 10.01.2020.

Görsel 13. Claire Zeisler, Private Affair I, 1986.https://www.artic.edu/artworks/65209 /private-affair-i, Erişim tarihi: 10.01.2020.

Görsel 14. Ferne Jacobs, Floating World, 2007.

https://www.nancymargolisgallery.com/ferne-jacobs, Erişim tarihi: 10.01.2020.

Görsel 15. Ferne Jacobs, The Round, 2007. https://www.nancymargolisgallery.com/fernejacobs, Erişim tarihi: 10.01.2020.

Görsel 16. Victoria Manganiello and Julian Goldman, Computer 1.0, 2018, https://www. victoriamanga niello.com/computer1, Erişim tarihi: 02.02.2020.

Görsel 17. Victoria Manganiello and Julian Goldman, Computer 1.0, 2018. Detay. https:// www.afanyc.com/the-art-of-tech, Erişim tarihi: 02.02.2020.

Görsel 18. Edith Meusnier, Sur Le Theme De L'eau Et Du Feu, 2010. https://www.edithmeusnier.fr/installations-in-situ/, Erişim tarihi: 02.02.2020.

Görsel 19. Atefeh Khas, Freesler Dreams, 2010. http://atefehtara.blogfa.com/1389/09, Erişim tarihi: 02.02.2020. 